\title{
Yapay Zekâ Resimleri ve Sanatın Başkalaşan Mecrası Üzerine
}

\author{
Artificial Intelligence Paintings and the Metamorphosis of Art
}

\section{Engin Aslan}

Dr. Öğr. Üyesi, Niğde Ömer Halisdemir Üniversitesi, Güzel Sanatlar Fakültesi, Resim Bölümü, ORCID ID: 0000-0001-78387151, engin.aslan@hotmail.com, enginaslan@ohu.edu.tr

\section{$\ddot{O} \mathbf{z}$}

Yapay zekâ (Artificial Intelligence- AI), tarafindan üretilen resimler, sanat alanında yeni tartışmaları da beraberinde getirmiştir. Özellikle bu alandaki çalışmalar 2014'ten bu yana çok ciddi gelişmeler göstermektedir. Yapay zekâ resimleri, sanatın kendi iç sorunsalları düşünüldüğünde, sanata ilişkin bir iddiada bulunması yönüyle oldukça dikkat çekmektedir. Nitekim sanatın özgün mecrasına değin, kendisine yeni alanlar açan yapay zekâ (AI)'nın, insanlığın bilim ve teknolojideki olağan gelişiminin dışında, sanatın insani yanı düşünüldüğünde; sanat ve hayat algımızda ne yönde değişim ve dönüşüm yaratacağı, önemli bir tartışma konusu olarak karşımızda durmaktadır.

Bu makalede, yapay zekânın (AI) algoritmik çalışma prensibi ve üretim sürecinin kavranılarak; sanat alanının mecrası ile sanatsal yaratım arasındaki sorunsallar ortaya konularak tartışılmıştır. Söz konusu tartışma alanları ise, sanatın gerçeklikle olan ilişkisi ile hem geleneksel ve modern yaklaşımlar çerçevesinde, hem de ortaya çıkan yeni durumun olanakları bağlamında değerlendirilmiştir.

Anahtar kelimeler: Yapay Zekâ, Algoritma, Sanat Mecrası, Sanatçı, Gerçeklik

\section{Abstract}

Artificial intelligence (Artificial Intelligence-AI), produced by the pictures, has brought new discussions in the field of art. Studies in this area have shown very serious developments since 2014. Artificial intelligence is a remarkable issue in terms of the fact that art makes a claim about art when it comes to its own internal problems. In fact, considering the humanistic side of art, apart from the usual development of human intelligence in science and technology, the artificial intelligence (AI), which opens up new spaces to art itself, and the way in which it creates changes and transformations in our perception of art and life is an important topic of discussion.

In this article, considering the algorithmic working principle of artificial intelligence (AI) and the production process, the problems between art and artistic creation are discussed. These areas of discussion have been evaluated in the context of the relationship between art and reality, both within the framework of traditional and modern approaches, and the possibilities of the new situation.

Keywords: Artificial Intelligence, Algorithm, The Metamorphosis Of Art, Artist, Reality 


\section{Giriş}

Yapay zekâ (AI), bilgisayar çağının başlangıcından günümüze değin güncelliğini koruyan ve evrensel boyutta toplumların ilgi ve merakını uyandıran bir olgu olarak karşımıza çıkmaktadır. İlk sibernetik çalışmalar alanında, kendisine önemli bir yer bulan, yapay zekâ araştırmaları, II. Dünya Savaşı'nın sonlarına doğru başlamıştır; ancak özellikle, son 10-15 yıl içerisinde hızlı bir ilerleme kaydedilen bu alanda, başta Amerika ve Çin olmak üzere birçok ülkede bulunan enstitü ve araştırma laboratuvarlarında önemli çalışmalar yapıldığını görüyoruz. Kimi bilim insanları ve bilgisayar yazılım mühendisleri bu konudaki gelişmelere dikkat çekerek, yapay zekânın insanlığın sonunu getirebileceği! ve hiç öngörülemeyen yeni problemler yaratacağı görüşünde birleşmektedirler. Örneğin, Facebook Yapay Zekâ Araştırma Laboratuvarı'ndan (FAIR) araştırmacılar tarafından geliştirilen Chatbootlar'ın kendi aralarında, araştırmacılar tarafından fark edilinceye kadar, yeni bir tür dil geliştirdikleri ortaya çıkmıştır. Tam olarak çözülemeyen bu şifreli dil, esasen söz konusu alan için heyecan verici olmasına rağmen, kimi nedenlerden dolayı, Facebook'un yazılım mühendisleri tarafından sistemin işleyişine son verilmiştir. Edward Fredkin ise, bu olguyu, insanlığın tarihsel ilerleyişinde bir kırılma noktası olarak görerek, şöyle bir tanımlama yapmıştır; "Tarihte üç büyük olay var. Biri evrenin yaratılışı, ikincisi hayatın başlangıcının olması, önemli derece eşit olduğunu düşündüğüm üçüncü şey ise, Yapay Zekâ'nın ortaya çıkışıdır" (Franchi ve Güzeldere, 2005, s. 1).

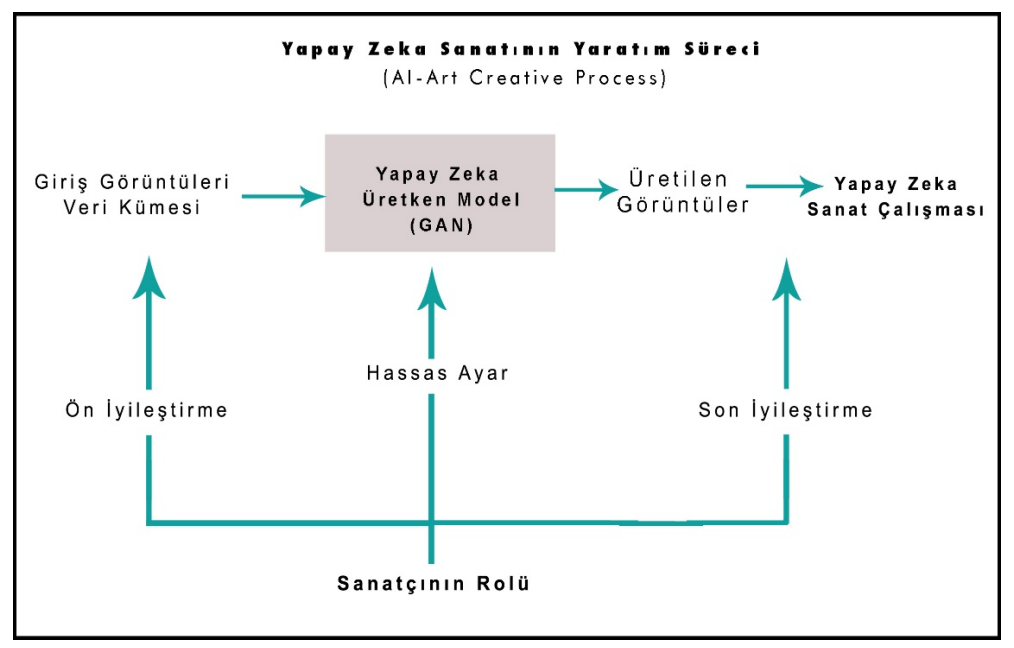

Görsel 1. Ahmed Elgammal, "Yapay Zekâ Sanat Yaratım Süreci”, 2018.

Amerika'nın Kaliforniya eyaletinde bulunan, Facebook'un yapay zekâ laboratuvarı ile Rutgers Üniversitesinden bilim insanlarından oluşan bir ekibin geliştirdiği, Generative Adversarial NetworkGAN (Üretken Karşı Ağ)'ın algoritmik çalışma prensibine göre, Yapay Zekâ'nın çalışma sistemi, herhangi bir sonuca ulaşıncaya değin, iki karşıt nöral ağın birbirleriyle mücadelesi veya bir nöral ağın bulguladığı sonuç verisini, bir diğeri yargılayarak, en iyi sonuca ulaşılması prensibine dayanmaktadır. Elgammal'ın, yapay zekânın yaratım sürecine ilişkin grafiği Görsel 1 dikkate alındığında, söz konusu algoritmanın çalışma sistemi ve buradaki sanatçının rolü (insan-makine işbirliği) arasındaki işleyişi göstermektedir. Melez sanat (Hybrid art) olarak adlandırılan yeni sanat biçimi, özünde; grafik tasarım programları, 3D yazıcılar ve yapay zekâ gibi teknolojik olanakları insan-makine işbirliği ile sanat ürünleri elde etme ilkesine dayanmaktadır. Ron Burnett'e göre:

Yapay zekâ yaratma çabaları büyük ölçüde, bilgisayarların gücüne ve enformasyonu elinde tutma ve kullanma kapasitelerine bağlıdır. Yapay zekâ, enformasyon işlemenin ve modellemenin bir metaforudur. Buradaki varsayım, bilgisayara yeni enformasyon tanıtıldığında bilgisayarın bu yeni enformasyonu, işlemlerinin bir parçası olan hâlihazırdaki modellere 
işleyebileceğidir. Bir dereceye kadar, bilgisayarın, aldığı enformasyonun sınırlarının ötesine geçmek ve öngörülebilir sonuçlar kadar öngörülemez sonuçlar da geliştirmek için 'zekâ'sını yeterli ölçüde kullanacağı umulur (Burnett, 2007, s. 175).

Resim alanına ilişkin söz konusu sistemin çalışma prensibi en temel anlamda, farklı tarihsel dönemler içerisinde yaratılmış sanat yapıtlarını, özgün niteliklerine göre kısa bir süre içerisinde çözümleyip, muhakeme ve kıyasla başka bir sonuç elde edilmesi yöntemidir. Google'ın "Deep Dream" (Derin Düş) adını verdiği bu sistemin, iddiası şu yöndedir: İnsanlar gibi derin düşünmek ve karmaşık örüntüler içerisinden ortaya yeni bir eser koymak. Bu yaklaşımla hareket eden bilgisayar yazılım mühendisi ve sanatçlardan oluşan çeşitli guruplar 2014'ten bu yana birçok resim elde etmişlerdir. Temelde insan yaşantısının, düşüncesinin ve yaratıcılığının ürünleri olan sanat yapıtlarının görselleri, sistemin veri tabanına girilerek sistemin, bir tür baskı resim üretimi yapmasıyla çalışma sonuçlanıyor. Ancak, son birkaç yıldan bu yana artarak devam eden, yapay zekâ resimlerinin ortaya çıkardığı bazı tartışmalar vardır. Bunlar, söz konusu resimlerin özgün olup olmadığı, Sanatın kendisine yeni bir yol açıp açmadığ1 ya da insan-makine işbirliğindeki yeni bir mecra olarak adlandırabileceğimiz "melez sanat" mı? gibi yeni tartışma konularıdır.

\section{Yapay Zekâ Resimleri}

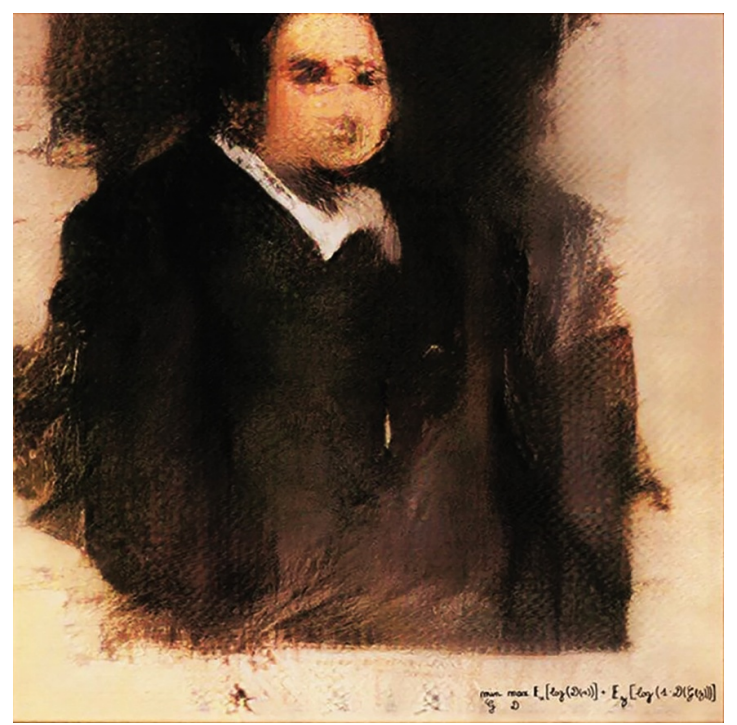

Görsel 2. Yapay Zekâ Ürünü, “Edmond Belamy’nin Portresi, $70 x 70$ cm, 2018.

2018 y1lı içerisinde, Gauthier Vernier, Hugo Caselles-Dupré, ve Pierre Fautrel'den oluşan Paris merkezli bir kolektif sanat topluluğu, daha önce bahsettiğimiz çalışma prensibiyle, GAN (üretken karşı ağ)'ın, veri tabanına 14. ve 20. yüzyıllar arasında üretilmiş yaklaşık on beş bin "portre resmi” yükleyerek; "Edmond Belamy'nin Portresi” (Görsel 2) adlı resmi üretmişlerdir. "Edmond Belamy'nin Portresi" adlı ürün, sanat alanında tartışmaları da beraberinde getirmiştir. Söz konusu resimden ayrı olarak, birçok resim, yine benzer algoritmalarla üretilmiş olmasına rağmen, New York'taki "Christie" müzayede evi tarafından 2018'in Ekim ayında, dünya çapında bir açık artırma ile satılan, "ilk yapay zekâ resmi” olma özelliği ile de sanat tarihinin kendi serüveninde, öyle ya da böyle yerini almıştır.

Sanat, insan yaşantısının, zihinsel işleyişinin ve düşünme biçiminin eylemselliğidir. Sanatçı ise, bu türden bir eylemsellikle hayatı biçimleyen, yeniden yaratan ve gerçekliğin yerine geçebilen içeriği, somutlayan kişidir bir bakıma. Buradan hareketle, veri tabanına sadece fotoğrafik imajlar yüklenen söz konusu cebirsel algoritma, ne türden bir sanat ürünü yaratabilir? Bilindiği üzere Batı Resmi, 19. yüzyıl sonlarında nesneler dünyasının dış görünümünü temel alan resim anlayışını terk etmiştir büyük ölçüde. 
Arthur C. Danto'nun konu bağlamındaki düşünceleri şöyledir: "Modernizmle beraber sanat, ayna yansıması resim anlayışından uzaklaşmıştır; hatta uygunluğun ölçütünü fotoğraf belirlemeye başlamıştır. Fotoğraf, imgeleri zapt edebildiği için ayna-yansıması resimlere nazaran avantajlıdır, fotoğraf imgeleri de olsa solmaya eğilimlidir elbette" (Danto, 2017, s. 14- 15).

Burada Danto'nun bahsettiği, bir yansıma ya da nesnelerin dış görünümlerinin sonsuza değin, zamandan koparıldığı fotoğrafların, geleneksel veya yerleşik anlamda resim kotarma anlayışıyla örtüşmemesi, reddetmesi veya "görüntü odaklı resim" anlayışının terkedilmesi bağlamında algılanmalıdır. Kentridge, 2003 yılında bir röportajında, resim yapma eylemine ilişkin şunları söylemiştir:

Her şeyden önce imgeye ulaşmak bir süreçtir, donmuş bir an değildir. (...) Ne çizeceğinize dair hisleriniz belirsiz olabilir, ama şeyler bir süreç sonunda meydana gelir ve bu süreç boyunca bildiğiniz şeyleri değiştirebilir, pekiştirebilir ya da tamamen dağıtabilirsiniz. Resim fikirlerin test edildiği bir zemindir, düşüncenin ağır çekime alınmış halidir. Bir fotoğraf gibi anında ortaya çıkmaz. Bir resmi kesin olmayan ve belirsiz bir biçimde inşa etmenin yolu, biraz da anlamı inşa etmektir. Bir şeyin açık seçik bir biçimde sonuçlanması, bu şekilde başladığ 1 anlamına gelmez (Kentridge, 2003, s. 8).

Yapay zekâ ise sonuç itibariyle var olan binlerce görüntüyü, karşıt ağ sistemiyle niteliksel ve niceliksel bir kıyasla işlem yapıyor olması, ortaya çıkacak olan ürünü, bir sanat ürünü kategorisine dönüştürmede yeterli olabilir mi? Nitekim daha en baştan bir kurgu ve yönlendirme söz konusu, dolayısıyla ortaya çıkacak muhtemel sonuç, manipüle edilmiş bir görüntüden başka bizlere özgün olarak ne sunabilir? Veri tabanına aktarılan imajlar üzerinden çalışan bu algoritma, en temel anlamda görüntüden görüntü üreten bir sistemdir denebilir. Bu bağlamda Gasset, portre resmi üzerinden giderek şunları söylemiştir:

Portre yapan bir geleneksel ressam, gerçek kişiyi bütünleyen sayısız niteliklerden, gerçekte kendi zihninde, keyfince, kabataslak seçtiklerini tuvale aktardığında o kişinin gerçeğini yakalamış olduğu iddiasındadır. Peki, acaba ressam o kişiyi resmetmek yerine, kendi fikrini, o kişi üstüne oluşturduğu şemayı resmetmeye karar verse ne olurdu? İşte o zaman tablo gerçeğin ta kendisi olurdu ve kaçınılmaz başarısızlık önlenirdi. Tablo gerçeğe öykünmeyi bırakarak, aslına dönüşürdü: bir tabloya-gerçekdışı bir şeye. (...) Nesneleri resmetmeyi bırakıp fikirleri resmetmeye geçmişlerdi: Sanatçı dış dünyaya karşı körleşen gözlerini içsel, öznel görünümlere çevirmişti (Gasset, 1992, s. 171-172).

Modernist sanatın, kuramsal altyapısını borçlu olduğumuz sanatçılardan biri olan Cézanne, nesnelerin dış görünümlerini esas alan bir bakışa sahip değildir ve resimlerinde imgeyi nesnenin bir parodisine de dönüştürmemiştir. Tersine, nesnelerin gerçekliğine ilişkin sorunsalı, kendi zihinsel gerçekliğinde yeniden yaratmış ve gerçeğin yerini tutabilen imgeler yaratmıştır. Nitekim Cézanne'ın sanatın gücü, buradan kaynaklanmaktadır bir bakıma. Zeynep Sayın, Cézanne'ın resimlerindeki imge-nesne arasındaki ilişkiyi şöyle yorumlamaktadır: "İmgelerin dünyada göndergesel bir karşıllı̆ı yoktur: göndergesellik tuvaldedir. Cézanne'ın öz göndergeselliği, kendi içinde soluk alan, kendini içeriden oyan bir mekân yaratır. Simgesel görme düzenini dışarıdan değil, içeriden yaran bir oyuktur bu: nesneler ile göz arasındaki ilişki, benzeşim uğruna benzeşim ötesi bir yasallık olarak yeniden tanımlanmıştır" (Sayın, 2009, s. 148).

Dolayısıyla bir noktayı gözden kaçırmamak gerekiyor; sanatın bütün bileşenleri düşünüldüğünde; bir imajın, insandan bağımsız olarak oluşturulup oluşturulamayacağ temel anlamda bir sorunsal ise bu bir ölçüde başarılmış görünmektedir. Ancak, sanat yalnızca sonuç odaklı bir süreç midir? Yoksa düşünüş, duygu, deneyim, özgünlük, başarı ve başarısızlıklar gibi yalnızca sonuca odaklı (görüntü oluşturma bağlamında) olmayan, süreçler toplamı mıdır? Burada; "Sanatım için hayatımı ortaya koyuyorum" diyen Van Gogh'un yapıtlarını hatırlamak gerekiyor, çünkü Van Gogh'un sanat yaşantısı, tek tek her 
bir yapıtının toplamından daha fazlasıdır. Nitekim kavramların ya da herhangi bir sistemin özgün niteliklerini kavramakla, onun yaratılması veya uygulamaya geçirilmesi konusunda, Ergüven şunları söylemiştir: "Demokrasiyi kâğı̈t üzerinde anlamakla demokratik olma, olabilme arasında nasıl bir ilişki varsa, herhangi bir felsefi sistemi yahut sanat yapıtının iç mantığını kavramakla, o sanat yapıtını üretmek arasında da öyle bir bağıntı vardır" (Ergüven, 1992, s. 17).

Yapay Zekâ tarafından son birkaç yıldan bu yana üretilmiş diğer çalışmalar, Görsel 3'de gösterilen portre resimlerdir. Söz konusu portreler, özellikle son beş yüz yıldır, sanat tarihinde iz bırakan eserlerden oluşan imajların, yapay zekânın veri tabanına girilerek, sonuca ulaşılan çalışmalardır. Bu resimlere üstünkörü bakıldığında bile hemen, Rönesans'tan Kübizm'e oradan Dışavurumcu sanata değin, bütün sanat dönemlerinin izlerini taşıdığı anlaşılmaktadır. Nitekim yaratılmış bir imgenin fotoğrafından ya da biçim bozmaya dayalı (manipülasyon) bir cebirsel algoritmanın ürettiği bu çalışmaların, özgünlügü ya da insana ait kimi özellikleri taklit etme noktasında, başarılı olsalar bile, sanat izleyicisine, hayatı anlama ya da anlamlı kılma donanımına dair ne gibi katkılar sunabilir? Konuya ilişkin, Picasso, konuşmalarından birinde şunları söylemiştir: "Önemli olan sanatçının ne yaptığı değil, ne olduğudur. Yaptığ1 elmalar on kez daha güzel bile olsa, Cézanne, Jacques Emile Blanche gibi yaşayıp düşünmüş olsaydı, beni hiç de ilgilendirmezdi. Bizi ona ilgi duymaya zorlayan şey Cézanne'ın kaygısıdır; işte Cézanne'ın bize verdiği ders budur" (Ashton, 2001, s. 37). Dolayısıyla her resim yapan kişinin sanatçı olmadığı gibi, her üretilen görüntünün de sanat değeri olduğu söylenemez.

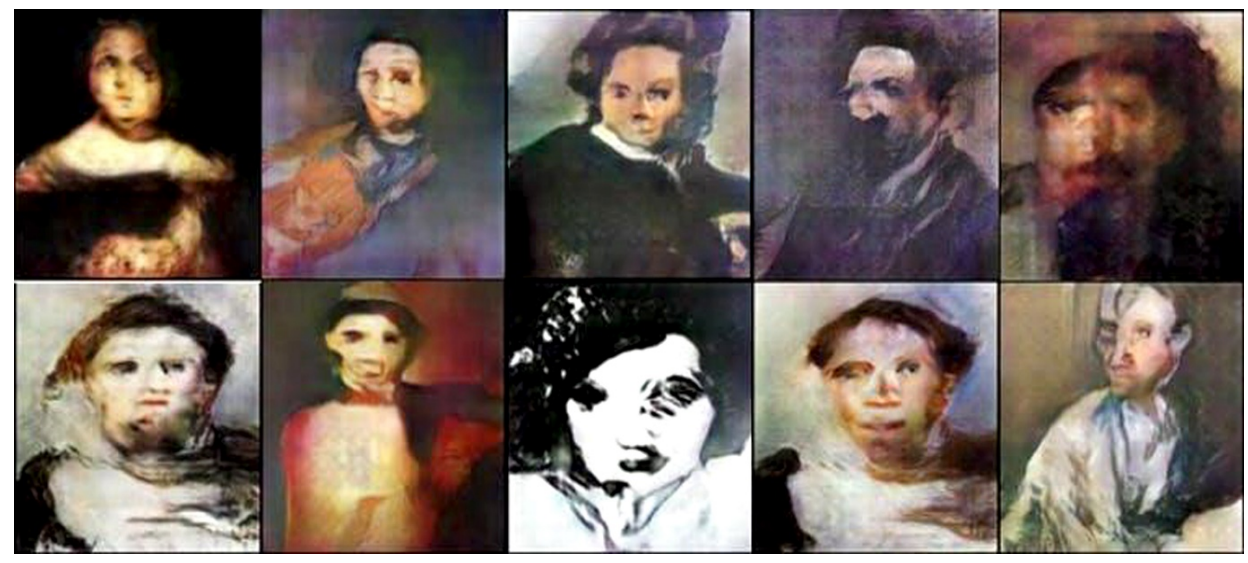

Görsel 3. Yapay Zekâ Tarafindan Son Birkaç Yılda Üretilen Portre Çalışmaları.

Fotoğraf üzerinden çalışan bu sistem, enikonu görüntüden görüntü üretmiş olmaktadır, bu durumda şaşırtıcı olan durum, belki de şöyle ortaya çıkabilirdi; veri tabanına yüzlerce Rönesans dönemi portresi yüklenen sistem, Kazimir Malevich'in "Siyah Kare"sine benzer bir resmi, sonuç verisi olarak bizlere sunacak olsaydı, bu durum bir ölçüde ilginç olabilirdi. Ancak, daha önce de bahsedildiği üzere, burada temel sorunsal, insanın düşüncesinden bağımsız olarak bir "görüntü" yaratmak ise, teknolojinin geldiği son verilere bakarak ve gelecekte olabilecekleri de göz önünde bulundurarak denilebilir ki, bu durumun çok çok ilerilere taşınacağı da somut bir gerçeklik olarak karşımıza çıkmaktadır. Picasso'nun yaşadığı tarihsel dönem itibariyle, 20. yüzyılın ilk çeyreğinde sinema ve fotoğraf alanındaki teknolojik gelişmeler doğrultusunda, figüratif resim yapmanın hala mümkün olup olmadığg sorusu üzerine, Picasso şu yanıtı vermiştir: "Tam tersine, bana göre, asıl şimdi mümkün bu. En azından, şimdi artık nelerin resim, nelerin resim olamadığını biliyoruz" (Ashton, 2001, s. 127). Daguerre'in fotoğrafi icat ettiği 1839 yılında, ressam Paul Delaroche'un "resmin öldügüne" ilişkin sözü, yaşanılan tarihsel dönemde son derece önemli teknolojik bir gelişme karşısında sanatçının, içine düştüğü hayret ve sanatına ilişkin duyduğu endişe, onun bu sözü söylemesini olağan kılmaktadır, ancak burada şunu da hatırlamakta yarar olacaktır; eğer fotoğrafın icadından sonra, resmin ölümü Picasso ve birçok sanatçı tarafında kabul edilmiş olsaydı, 
biz hiçbir zaman "Guernica" gibi bir başyapıtı bilemeyecektik. Delaroche'un verdiği bu tepkiye karşın Picasso, yukarıda da değindiğimiz gibi: “....asıl şimdi nelerin resim olmadığını biliyoruz” sözünün ne anlama geldiğini ise Picasso'nun yapıtlarından anlıyoruz.

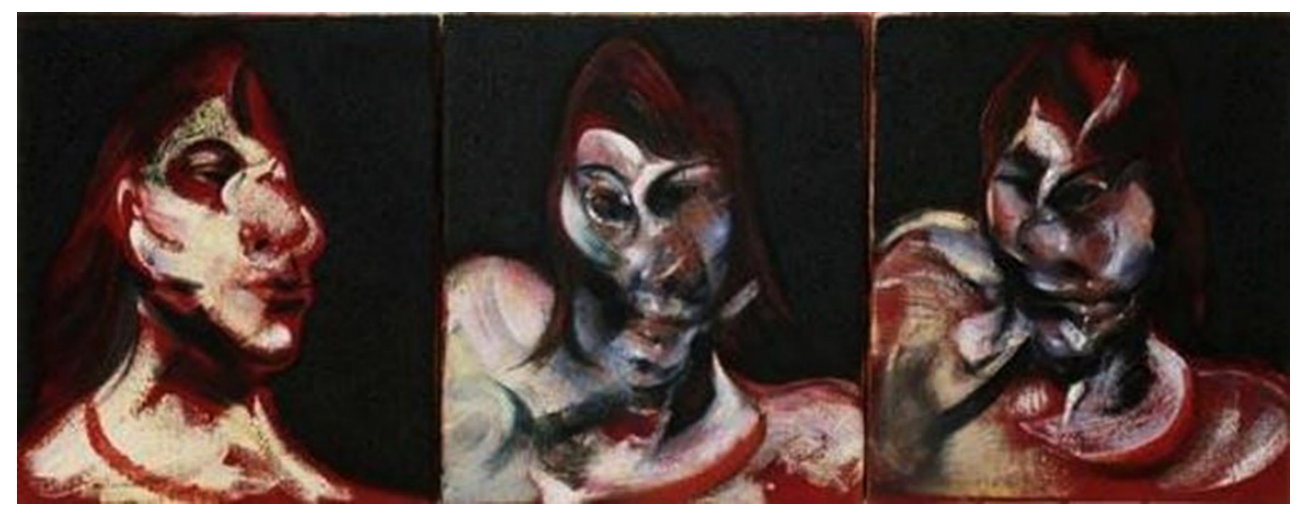

Görsel 4. Francis Bacon, Henrietta Moraes 'in Üçlü Portre Çalışmasl, Tuval Üzerine Yağllboya,

$$
3 \times(35.9 \times 30.8 \mathrm{~cm}), 1963 .
$$

Yapay zekâya ait Görsel 3'de sunulan diğer portre çalışmaları ile 1963 tarihli Francis Bacon'ın "Henrietta Moraes'in Üçlü Portre Çalışması" (Görsel 4) arasındaki büyük benzerlikler görülmektedir. Söz konusu resimler, eğer bir sanatçı tarafindan yapılmış olsaydı; etkilenmenin ötesinde, temellük sanatı (Appropriationism) olarak değerlendirme alanı içerisine almak çok da güç olmayacaktı. Ancak burada, temellük sanatı bağlamında bir değerlendirme yapılabilmesi, esasen ortaya çıkan ürünün, tamamen bir kopya, taklit vb. alanların içerisinde mi, yoksa sanat tarihinde, neredeyse izlerini Roma dönemi heykellerine değin sürebildiğimiz ve oradan hem modern hem de post-modern sanatın içerisinde kendisine yer bulan bir sanat biçiminden mi, söz etmek gerekiyor? Bu durumda, bu sorunsala doğrudan yanıtlar vermek biraz güçleşmekle birlikte, yapay zekâ resimleri için söz konusu kavramı kullanırken; en temel anlamda, sanat tarihindeki herhangi bir yapıtı referans alan bir "alıntılama"dan mı? Yine söz konusu yapıtın Aura'sına yönelik bir "saldırı" mı? Yoksa sadece "bir benzerini üretme" amacı bağlamında mı ele almak gerekir? Yapay zekâ ürünleri bağlamında; bugüne kadar elde edilen sonuçlar düşünüldüğünde, sosyal-siyasal bağlamlarından kısmen de olsa kopuk olan bir tür "saldırı" ve bir tür "benzetme" amacı güden "yeniden üretim" bağlamına daha yakın olarak algılanmaktadır. Burada, örneğin Picasso'nun "Kore'de Katliam” (1951) adlı eseri üzerinden giderek, bir örnek verilecek olursa; Picasso, Goya'nın "Madrid'de 3 Mayıs 1808" adlı eserini hem sosyal-siyasal hem de biçimsel olarak kendi resmine referans almıştır ki Picasso'nun hayatı anlama ve kavrama noktasındaki politik tavrı göz önüne alındığında, Goya'nın söz konusu eserine karşı, ne bir "saldırı" ne de "bir benzerini üretme" düşüncesi vardır. $\mathrm{O}$, sadece insanlığın kolektif hafizasında "masumların katli" olarak kazınmış ve bir tür barbarlık ve şiddeti meşru kılan siyasal gücün, benzer bir anlayışla da 20. yüzyılda kendisine karş1lık bulan; ABD'nin Kore'de sivil halka yaptığı, benzer bir katliam arasında, bir tür siyasal benzerlik ilişkisi kurmasıyla, Goya'nın eserinin, insanlığa tekrar tekrar hatırlatılması gerektiği bağlamında düşünmüş ve onu onurlandırmıştır bir bakıma. Dolaysıyla burada üzerinde durulması gereken asıl nokta halen, bir sanat ürününün; nasılına değil niçinine verilecek yanıtlar üzerinden giderek yapılan anlamlandırmalar bütünü olarak düşünmek gerektiğidir. Bu türden örnekler, sanat tarihinde, Otto Dix’ten Beckmann'a değin birçok sanatçı özelinde vermek mümkün, ancak temel problem halen; söz konusu yazılımın, kesintisiz olarak, enformasyona bağlı kalması ve yönlendirmeyle "sonuca odaklı bir üretim" yapma yeteneğinde saklı görülmektedir. Nitekim daha önce de üzerinde durduğumuz bir noktayı önemle vurgulayan, yukarıdaki örneklerden (görseller) anlaşıldığı üzere, algoritma, veri tabanına girilen imajlar üzerinden çalıştı̆̆ı için, özgün bir sanat yapıtı yaratma koşulu, belli bir ölçüde elinden alınmış 
olmaktadır bir bakıma. Örneğin Claude Monet'in "Saman Yığınları" adlı eseriyle, ilk kez karşı karşıya kalan Kandinsky'nin şu sözlerini hatırlayalım:

Belirsiz bir biçimde, bu resmin nesnesinin eksik olduğunu hissediyordum. Aynı zamanda, şaşırarak ve kafam karışarak, resmin beni sarmakla kalmayıp silinmez bir biçimde belleğime kazındığını ve sürekli olarak, ister istemez, en son ayrıntısına kadar gözlerimin önünde canlandığını fark ettim. Ama iyice anladığım bir şey varsa o da, paletin bana o zaman kadar gizli kalmış, aklımın ucundan bile geçmeyen ve bütün düşlerimi aşan gücüydü. Resim masalsı bir güç ve görkem kazanıyordu. Ama farkında olmadan, nesnenin resimde vazgeçilmez bir öğe olduğu yolundaki kanım da sarsılmıştı (Kandinsky, 2009, s. 113).

Burada, Monet'nin söz konusu resmi; Kandinsky'nin beklentisini aşan bir düşünüş ve resmin yapılanmasına ilişkin kanılarının yıkıldığı bir karşılaşma anı olarak düşünmek gerekiyor. $O$ güne değin gelinen tarihsel süreçte belli kodlamalarla edinilmiş yerleşik bakma biçimi, Kandinsky'nin sanatında bir dönüm noktası olarak; onun, doğaya, nesneye ve hatta müziğe karşı olan bakış açısını bütünüyle değiştirmiştir denilebilir. Yapay zekâ resimleri, bu açıdan düşünüldüğünde; bizlerde bu denli bir heyecan ve hayatı anlama-algılama noktasında bir dönüşüm yaratıp yaratmadığı da üzerinde düşünülmesi gereken bir olgu olarak karşımızda durmaktadır.

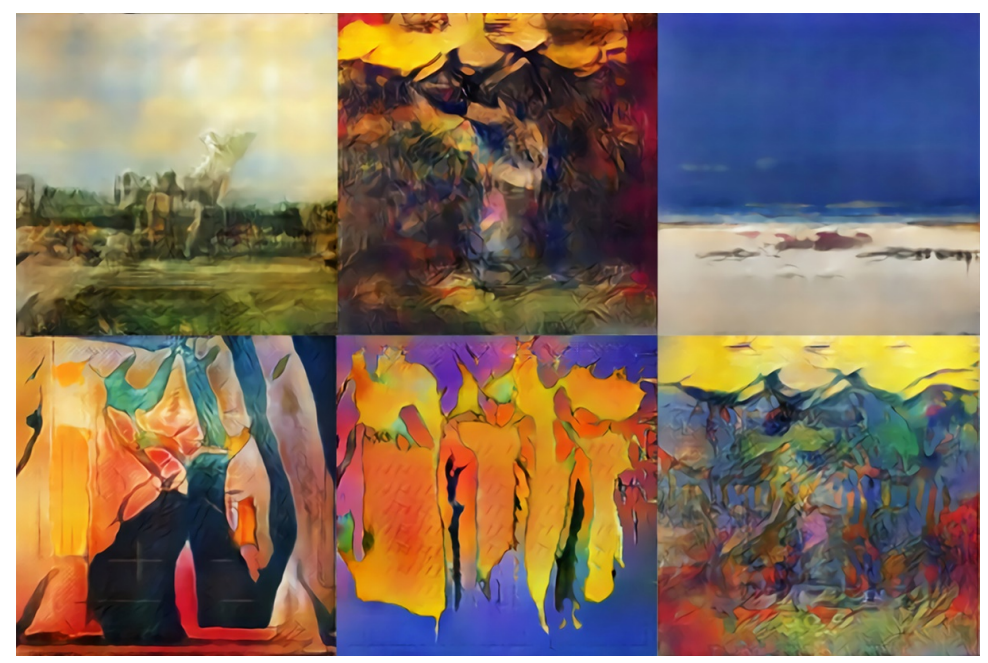

Görsel 5. Yapay Zekâ Tarafindan Son Birkaç Yılda Üretilen Diğer Resimler.

Yapay zekâ tarafından üretilen portre çalışmalarının yanı sıra, Empresyonist resimlerden 20. yüzyıl soyut resimlerine kadar, binlerce görsel, GAN'ın (Üretken Karşı Ağ) veri tabanına yüklenerek elde edilen, diğer resimler (Görsel 5) tüm dünyada, özellikle internet kullanıcıları tarafinda oldukça ilgi görmüştür. Ancak, burada önemli bir noktayı göz ardı etmemek gerekir; söz konusu resimler, daha ilk bakışta özellikle 19. ve 20. yüzyıl resimlerini doğrudan çağrıştırmaktadırlar. Her resim için ayrı ayrı üzerinde durulabilir, ancak sonuç olarak bunlar, birer sanat yapıtı olmaktan çok uzak ürünlerdir ve daha çok renklendirilmiş bir yüzey gibi durmaktadırlar. Facebook'un yapay zekâ laboratuvarı ile ortak araştırmalar yapan Rutgers Üniversitesi'nden Ahmed Elgammal, üretilen görüntüler ile sanat-estetik sorunsalı bağlamında şunları söylemiştir: "Yaratıcı ve vurucu bir şey istersiniz, ama aynı zamanda çok da aşırıya kaçmaktan ve estetik olmayan bir şey yapmaktan kaçınmanız gerekir" (Baraniuk, 2018). Elgammal'ın söylediklerine bakılırsa, daha en baştan söz konusu ürünler, birer sanat yapıtı olma ön koşulunu yitirmiş görünüyorlar; çünkü "izleyicinin tepkisini esas alan bir düşünme-yapılandırma biçimi”, Kitsch'in varoluşsal yapısını, eksiksiz bir biçimde tamamlamaktadır. Clement Greenberg, 1939 tarihli "Avangard and Kitsch” adlı ünlü makalesinde şöyle söylemiştir: 
Kitsch, özgün kültürün bayağı ve akademikleştirilmiş suretlerini hammaddesi olarak kullanarak hitap ettiği kitleyi selamlar ve bu bilgisizliği körükler. Kârlarının kaynağıdır. Kitsch mekaniktir ve formüllere göre işler. Kitsch dolaylı olarak yaşanan bir tecrübe, taklit duygulardır. Kitsch üsluba göre değişir ama özünde her zaman aynı kalır Kitsch, çağımızda, hayatta ne kadar sahte şey varsa hepsinin bir simgesidir. Kitsch müşterilerinden paraları hariç hiçbir şey talep etmiyormuş gibi davranır, onların vakitlerini bile istemez (Greenberg, 1939, s. 5).

Söz konusu resimlerin insan elinden çıkmış resimlerle karıştırılır hale gelmesi ise başlı başına, ciddiye alınması gereken bir sorun olarak düşünülmelidir; çünkü bu birbirinden ayırt edilemeyen boyama biçimi; algoritmaların, sanatçı yapıtlarından GAN'ın (Üretken Karşı A ̆g) çalışma sistemiyle bulguladığ1 bir biçimleme yöntemidir. Ancak, birbirine giderek benzeyen bu biçimleme pratiği, insanın makineyi taklit etmesinden kaynaklanmaktadır. Nitekim özellikle, 15-20 y1ldan bu yana, bir veya birkaç görseli temel alarak ve bazı bilgisayar programlarının efekt olanaklarıyla, başka bir görüntü elde edilmektedir. Elde edilen bu görüntüler de birebir kopyalanarak, imajdan imaj üretilmektedir. Sanatın kavranılması bağlamında, eksik bir düşünme biçiminden kaynaklı bu durum; tüm dünyada özellikle genç sanatçı adayları tarafından, tek doğru gibi algılanarak, birbirine benzeyen ve hatta söz konusu programlarından elde edilen görüntülerle karıştırılır hale gelmiş durumdadır. Kuspit'e göre: "Teknoloji, bir yandan alternatif bir ilham kaynağı sunarken bir yandan da bilinçdışının güvenilirliğini ve değerini azaltmak için yapılan son cesur girişimdir. Postmodern dönemde eski ve modası geçmiş olarak görülen modern sanat, yeniden modernleştirme kılıfi altında kasıtlı olarak yok edilmektedir” (Kuspit, 2006, s. 120).

Kuspit'in bakış açısına göre, burada yapmış olduğu değerlendirme oldukça dikkate değer bulunmalıdır; çünkü Postmodern anlayışın bir tür saldırı alanı olan modern sanatın, kitlelerce, henüz tam anlamıyla kavranamamışken onu, tümden reddetme noktasına getirilmesindeki sanat-piyasa kavramlarıyla ve onun teknoloji ile işbirliği konusundaki organik bütünlüğü gözden kaçırılmamalıdır. Sanatı bir tür eğlence olarak kanıksayan Amerikan toplumu ki bu tüm dünyada da oldukça yüksek bir oranda görünmektedir, kile kültürü bağlamında, sanatın üzerinde düşünülmesi gereken bir olgu olmasından çok, sanatı, sansasyonel boyutlarıyla ilgilenilmesi gereken bir mecra olarak algılamaktadırlar. Henüz modern sanatı kavrayamamış bu kitleler, büyük ölçüde. Kitsch'in çeşitlemelerini yüceltmekte ve benimsemektedirler. Nitekim yukarıdaki örnekte (Görsel 4) anlaşıldığı üzere, burada insanın makineyi yönlendirmesiyle oluşturulan bir ürünün ve ortaya çıkan bu ürününü ise biricik bir şeymiş gibi, insan tarafindan tekrar kopyalanması-taklit edilmesi söz konusu olmaktadır. Bu durumda, insanın varoluşsal mevcudiyeti ve onun, kişiliğini oluşturan genetik kodlar hariç, büyük ölçüde duygularından ve yaşamsal deneyiminden kaynaklı, elde ettiği sanat pratiği ve düşünce biçimi bir bakıma terkedilmeye mahkûm bırakılmaktadır. Dolayısıyla, "görüntü odaklı" bir sanat anlayışı karşısında; bunu niçin? hangi nitelik ve içerikle yapılandırıyoruz? Bu sorularının cevaplarını temel alan, bir sanat bilincini ya da sanatı belli bir düşünüş ve uğraş alanı içerisine almış genç sanatçı adayları tarafından, bir hareket noktası olarak algılanması gerekmektedir.

Söz konusu resimlerin, "renklendirilmiş birer yüzey" gibi algılanmasının en temel noktası, insan yaratımından ortaya çıkan bir yapıtın, fotoğraf makinesi yardımıyla başka bir yüzeye aktarılması (imaj), bunu ise başka bir algoritmanın veri tabanına girerek, ondan, somut bir ürün alma koşuluyla yeni bir görüntü elde etmesinin sağlanması sorunsaladır. Bir imgenin önce imaja, bir imajın ise tekrar imgeye dönüştürülmesiyle yapılandırılmaya çalışılan bu sistemin, elde ettiği ürün; inandırıcılığını yitirmeye, imgenin, göz ile araya koyduğu anlam aralığını, giderek, birbiri üzerine kapatarak sıradanlaşmaktadır. Dolayısıyla bu resimlerle izleyici arasına giren, mekanik aralık, onun, bir algoritma ürünü olmasından çok, onun, henüz resmin yapılandırma sürecine ilişkin izlenen yolun, sığlığından kaynaklanmaktadır. İnsana ait duygu ve deneyimler olmaksızın, bu türden bir yazılımın, veri tabanına girilen ve izlenen bu çalışma yöntemi; her defasında benzer sonuçları elde edecektir. 


\section{Sanatın Başkalaşan Mecrası}

Amerika, II. Dünya Savaşı sonrasında, özellikle Avrupa'nın içine düştüğü bunalımlı dönemi bir firsata dönüştürerek kurguladığ1; hem soyut sanat ve türevlerini hem de sanat-piyasa ilişkisi bağlamını, sanatın yeni mecrası olarak kabul ettirmiştir. Andy Warhol'un İşadamı-Sanatçı kavramını ortaya atması; bir Deha'nın buluşu olarak değil, değişen-değiştirilen sanat algısının bir yansıması olarak düşünülmelidir. Nitekim Warhol, dönemin ruhunu şöyle tanımlamıştır: "Piyasa sanatı, Sanat'ın ardından gelen aşamadır. Ben bu işe ticari sanatçı olarak başladım ve piyasa sanatçısı olarak bitirmek istiyorum. Adına ister 'sanat' densin ister başka bir şey, bu işi yaptıktan sonra piyasa sanatına yöneldim. Sanatçı İ̧̧adamı ya da İşadamı Sanatçı olmak istedim" (Kuspit, 2006, s. 161). Sanat-piyasa ilişkisi bağlamında, Warhol'un "Pop Sanat" ve yine kendisini belirli ölçülerde eklemlediği; ancak özünde bir başkaldırı olan "Dada" hareketi ile onun piyasayla uyum içerisinde olduğu, hem ortaya koyduğu ürünler hem de sanat anlayışından kaynaklı düşünme biçimi onu, kendisinin de tanımladığı üzere; İşadamı-Sanatçı rolüne indirgemiştir. Tamda burada, Kuspit'in Postmodern sanatı tanımladığı şu cümlelerini hatırlamakta gerekiyor:

Postsanat tamamen sıradan sanattır- gündelik sanat olduğuna şüphe yoktur; ne Kitsch ne de yüksek sanattır; bu ikisinin ortasında duran, gündelik gerçekliği çözümlemiş gibi yaparak aslında onu allayıp pullayan sanattır. Postsanat, gündelik gerçekliğe eleştirel yaklaştığını iddia eder, ama aslında farkında olmadan onunla uyum içinde kalır (Kuspit, 2006, s. 105).

Bu tanımlama, Warhol ve günümüzde, onun izlediği yoldan giderek bu konudaki tartışmaları daha da ileri boyutlara taşıyan Jeef Koons ve Damien Hirst gibi post-sanatçılar bağlamında düşünüldügünde; sanatın yeni mecrası, sanatın özerk alanının geleceğin titreşimlerini içeren, bir düşünce ya da pratiğin yapılanmasından değil, her şeyin metaya dönüştüğü kapitalist düzen içerisinde, bir bakıma bizatihi piyasanın "kendisi" haline gelmesinden kaynaklı bir olgu olgudur artık. Çağdaş/Güncel sanat kavramları, günümüzde uluslararası galerilerin, müzayede evlerinin ve iş dünyasıyla iç içe olan küratörlerle, neredeyse bütünleşmiş bir yapıdadır. Kitle kültürü, piyasa ve çağdaş sanat bağlamında Julian Stallabrass şunları söylüyor: "gençlik imgesine yapılan vurgu, dergilerde basıldığında güzel gözüken eserlerin her yanı kuşatması ve 'yıldız sanatçı' mefhumunun yükselişi; kültür ve moda endüstrisine kucak açan ve sponsorların gözlerini parlatan sanat eserleri; önceden tanımlanmış ve denetlenen durumlar haricinde eleştirinin noksanlı̆̆ı" (Foster, 2008'den aktaran Boren, 2015). Dönemin ruhunu büyük ölçüde özetleyen Stallabrass'ın bu düşüncelerin belki de üzerinde durulması gereken en önemli nokta; "eleştirinin noksanlığı" şeklindeki açıklamasıdır. Bu durum, esasen sanat-piyasa ilişkisi bağlamında düşünüldüğünde, kaçınılmaz olarak gerçekleşmektedir; çünkü kendi varoluş nedenini borçlu olduğu yapıdır aynı zamanda. Bu yüzden ister istemez bu yapıyla uyum içerisinde hareket etmeleri beklenmektedir. Hal Foster, tam da bu konuda şunları söylüyor:

Bir zamanlar, avangard sanat kitsch'le karşıtlı̆̆ üzerinden tanımlanırdı; kitsch'i bağrına basmasının da hayret ve şaşkınlık uyandırıcı bir yanı olabilir, ama öncü bir meydan okuma ya da başkaldırı içermediği kesindir. Bilakis: "Her zaman, hiçbir seyircimi yabancılaştırmayan işler üretmeye çalıştım," diyor Koons. "Eserlerimle insanlara geçmişleriyle, kimlikleriyle barışmalarını telkin ediyorum." Koons'a göre, bu geçmiş, bu kimlik, "kitle kültürü tarihinin" sembolleri tarafından oluşturulur ve var olduğu haliyle "mükemmeldir (Foster, 2008' den aktaran Boren, 2015).

Koons'un da belirttiği gibi manipüle edilen ve sosyal-siyasal gerçekliğin algılanmasıyla ilişkisi bulunmayan bir "kimlik" kavramı, yalnızca üniter devletlerin bütünlüğüne bir sorunuymuş gibi toplumlara benimsetildiği gibi, sanattaki yansıması da bu türden ucu açık bir "yapay tartışma" alanları açılması, başta Amerika olmak üzere ve batı toplumlarındaki genel siyasi yapıların, tam da istediği 
tartışma alanlarıdır. Nitekim herhangi bir sitemin aksayan yanlarını eleştiriyormuş gibi görünüp, o yapıyla tamamen uyumlu halde olan bir sanat anlayışı, Postmodern sanatçılar için zaten üzerinde durmaya bile gerek duymadıkları bir düşünce alanıdır denebilir. Warhol'un hayali gerçekleşmiş gibi görünmekle birlikte, sanat alanının kendi içine çöküşü ve teslimiyeti, uluslararası ölçekte düşünülecek olursa, çok daha kısıtlı olanaklara sahip olan sanatçılardan, sanatın evrensel değerlerinden ve belki de Berger'in de önemle vurguladığı, gerçek sanatçı kişiliğinden söz etmek gerekiyor:

Günümüzde sanatçı toplumda bambaşka bir yer tutmaktadır. Artık yapımcı olarak değil, eserinde dile gelen görüş ve hayal gücünün niteliğine göre değer bulan biridir. Öncelikle sanat yapan bir adam değildir; bir insan örneğidir, onu örnekleştiren de sanatıdır. Bu hem felsefi düzeyde hem de değerlendirme düzeyinde, sanat eserlerinin piyasadaki herhangi bir metayla aynı işlemi gördüğü kapitalist düzende bile geçerlidir (Berger, 1987, s. 106).

Berger'in bu düşünceleri, göz önüne alındığında, uluslararası sanat piyasasının belli aktörlerinin dışında, teknoloji ve internetin tüm dünyada yaygın kullanımı, bir ölçüde, daha demokratik bir sanat ortamı da sağlamaktadır. 20. yüzyılın başlarında Paris, sanatçıları ve entelektüelleri kendisine çeken ve sanatın merkezi konumundaydı, bu durumun birçok nedeni olabileceği gibi, belki de, en önemli neden; her insana, her türden düşünceyi ifade edebilecek bir özgürlük alanı sunmasından ve bunun üstesinden gelebilecek tarihsel birikime sahip olmasından kaynaklanmaktaydı bir bakıma. Yaşanılan bu tarihsel süreçte ise, bu türden sanat merkezleri halen, eski gücünü kısmen de olsa korumakla birlikte, enformasyon çağının getirdiği yeni mecralar, hem sanatçılar hem de izleyiciler açısından en özgür ve adilane mecraları sanal ortamda da olsa sağlamaktadır.

Hızla gelişen teknoloji kaçınılmaz olarak ona, uyum içerisinde kitleleri de yaratmakta ve bu olgunun dışında kalma fikri ister istemez anlamsızlaşmaktadır. Ancak, burada önemle üzerinde durulması gereken bir nokta var ki o da, teknolojinin bu hızlı ilerleyiş̧i karşısında birey olarak, konumumuzu belirlemek noktasındaki, kişisel yetkinlikler düzeyidir. Başka bir deyişle, bir birey olarak kitle kültürü içerisinde, sisteme tamamen entegre olmuş ve bu durumu kanıksamış bir insan örneği olmak ya da gerçeklik ile sanal olan arasındaki çizginin bulanık hale gelmesini, bir tür farkındalık uyarımı olarak görerek, buna göre kendisini konumlandıran bir insan olmak. Benjamin'in kitle ve sanat ilişkisi bağlamındaki düşünce şöyledir: "Kitleler, kendilerini oyalayacak bir şeyler ararlar, oysa sanat, izleyicisinden kendini toplayıp odaklanmasını ister. Bu aslında herkese ortak olan bir alandır" (Benjamin, 2014, s. 75).

Kitle kültürü her ne kadar demokratik görünse de nitelik ile doğru orantılı bir biçimde işlemez; doğası gereği herkesi kapsama fikrinden hareket ettiği için, bireylerin ne eğitim seviyesi, ne düşüncesi, ne de hayatı kavrama biçimi ile ilgilenmez. Dolayısıyla, sanat alanı bağlamında düşünüldüğünde, çok daha vahim sonuçlar ortaya çıkmaktadır; aynı ekranda yan yana örneğin; Picasso'nun bir yapıtı ile Kitsch bir ürünü yan yana görebilmekteyiz. Bu durum ona bakan, milyonlarca insan tarafından hiç de rahatsızlık duyulacak bir şey olarak algılanmaz. Tam da burada Ergüven, yazın sanatı üzerinden, şunları söylemektedir:

Sözcük ile temsil ettiği arasında dolaysız bir ilişki vardır; en azından öngörülen şey budur. Dolayısıyla, imgelem gücüne karşı bir güvensizlik söz konusu olup, sentaktik öğelerin çözümlenmesi yoluyla herhangi bir şeyin sezgisel tasarlama olasılığ peşinen dışlanmıştır. (...) Etkinin pazarlanabilir duruma geldiği bu süreçte ise bütünüyle Kitsch'in yasaları egemendir artık (Ergüven, 1992, s. 126).

Çevrimiçi olarak yapılan bir araştırmada, yapay zekâ resimleri daha çok ilgi beğeni toplamıştır. Ancak, bu türden bir örneği temel aldığımızda, popüler kültürün ve Hollywood estetiğinin bu denli belirleyici olduğu bu tarihsel süreçte, yüksek kültürün en temel sanat alanlarından biri olan resim için, insanların 
hangi bilgi ve birikimleriyle karar verdiği ölçütlerinin niteliği konusunu, dikkate alınmalıdır. Huelsenbeck'e göre: "Sanatın ölümü, sanatın kitle toplumunda sürekli olarak eğlence ile karıştırılmasıyla ilgilidir. Kitle insanın sanatı nötrleştirmesinin bir başka yoludur bu. Sanattan zevk alması için onu sıradanlaştırması gerekir." (Kuspit, 2006, s. 185). Nitekim teknolojik cihazların, insan hayatının neredeyse en önemli parçası haline gelmesiyle, her gün gözümüze gelen binlerce görüntü üzerinden düşünülecek olursa, bu türden bir saldırıyla baş edebilecek bir bilgi donanımı olmaksızın, sanat ile sanat olmayan arasındaki fark1, algılama konusunda karar verebilecek bir yetiye sahip entelektüel bireylerin, kitleler içerisindeki niceliği çok fazla olmasa gerek. Huelsenbeck'in kitle kültürü ve sanatın ölümüne ilişkin yapmış olduğu tanımlama daha önce de belirttiğimiz çoğu temel sorunsalları özetler gibidir. Nitekim sanatın mecrası başkalaşmışıır ve başkalaşmaktadır; ancak insana özgü en temel belirleyici özellikler halen ortada dururken, sanatın düşünsel-duyuşsal niteliklerini sıradanlaştıran bir yaklaşım ise enikonu ona, karşıt bir hareketi de beraberinde yaratacaktır. Dolayısıyla, bir sanat ürününü değerli kılan en temel unsur, bir bakıma belki de onun ardındaki hikâyesinden kaynaklanmaktadır. $\mathrm{Bu}$ bilinçle hareket eden birçok sanatçı halen dünyanın birçok ülkesinde yapıtlar ortaya koymakta ve yaşadıkları çağın bilincini bir tür direnç odağı olarak görmekte ve ona göre kendilerini konumlandırmaktadırlar.

\section{Sonuç}

Teknolojinin geldiği son nokta ve gelecekte olabilecekler de düşünüldüğünde; kaçınılmaz olarak insanmakine işbirliğinden doğan (melez sanat) ki bunun, zaten uzun zamandır örnekleri mevcut, yeni bir tür sanat mecrası olarak düşünülmesi gereken bir olgu olarak karşımıza çıkmaktadır. Yapay zekâ araştırmalarında ise gelinen aşama, geçtiğimiz yüzyılın son çeyreğine göre, artık çok daha ileri boyutlara ulaşmış durumda. Öyle ki, "dokunma duyusu" üzerine bir araştırma enstitüsü; insanın dış gerçekliği algıladığ1, deneyimlediği ve bu deneyimleriyle; düşünce, kanı ve duygu gibi insana özgü nitelikleri taklit eden "yapay sinir ağları" geliştirmeyi başarmıştır. Bu gelişme ile birlikte, yapay zekânın mekanik uzuvları, dış dünyayı kendi deneyimleriyle tanıyarak, özgün belleğini oluşturabilecektir. Bu türden ilerlemelere baktığımızda, belki henüz bu konuda kesin hükümler vermek biraz erken gibi görünmekle birlikte, insanoğlunun yine de en karmaşık ve en yaratıcı varlık olduğunu unutmamak gerekiyor bir bakıma. Nitekim bu gelişmeleri olanaklı hale getiren de yine insanın yaratıcı zekâsı değil midir? Dolayısıyla, bilgisayar teknolojisinin bu tür olanaklarından, günümüzde sanatçılar yararlanmaktadır ve yararlanmalıdır da; ancak sanatta gerçekliğe ilişkin alanı ıskalayarak yalnızca programların sunmuş olduğu olanaklara odaklanmanın da hiçbir anlamı olmayacaktır. Burada bir düşünme biçimi olarak, bir sanat ürününün yaratımı ile görsel efektlerin, kendi yaratıcısını manipüle etmesi ile ilgili bir durum söz konusu vardır ki bu da, sanatın varoluşsal koşulunu ortadan kaldırmaya ve "her şeyin sanat ürünü sayılabileceği”, Postmodern anlayışın dayanılmaz hafifliğine bir katkı sunmaktan öteye de gitmeyecektir.

Giderek insansızlaşan ya da insansızlaştırılmak istenen bir sanat anlayışına karşı, daha insani olan alanları savunmak da bir tür sanatçı duyarlılığı ve duruşu bağlamında bir direnç alanı olarak yer bulacaktır. Herhangi bir olay ya da bir olgu karşısında birbirinden çok farklı düşünme biçimleriyle insanlar çoğu kez, insana özgü ve ön görülemeyen davranış veya reflekslerle kendilerini ifade ederler; ancak yapay zekânın pragmatik çalışma sisteminin önünde, en azından şimdilik, insana özgü nitelikleri ifade edebilme konusunda kat etmesi gereken uzun bir yolunun olduğu da açıkça görülmektedir. $\mathrm{Bu}$ türden tartışmalar, insanın yaratıcılığına, onu harekete geçiren doğasına karşı yeni mecralar açmaktadır, belki de en önemli olgu, bu tartışma alanlarının genişlemesidir. Nitekim yapay zekâ tarafından üretilen sanatın sınırları nereye kadar giderse gitsin, belli bir gerçek var ki o da insanı, asla sanat yaratımlarından alıkoyamacağıdır; çünkü sanatı değerli kılan şey, insanın; yaşayış, düşünüş, duygu ve bilme biçimi olarak somutlanan yaratım süreçlerinin toplamıdır da ondan. 


\section{Kaynakça}

Ashton, D. (2001). Picasso konuşuyor. (M. Y1lmaz ve N. Yılmaz, Çev.). Ankara: Ütopya Yayıncılık.

Baraniuk, C. (2018, 21 Eylül). Yapay zekâ ressamlar sanata yeni tarzlar getiriyor! (M. Can, Çev.) [Blog yazıs1]. Erişim adresi: https://rasyonalist.org/yazi/yapay-zeka-ressamlar-sanata-yeni-tarzlargetiriyor/

Benjamin, W. (2014). Pasajlar. (A. Cemal, Çev.). İstanbul: Yapı Kredi Yayınları.

Berger, J. (1987). Sanat ve Devrim. (B. Berker, Çev.). Ankara: V Yayınları.

Burnett, R. (2007). İmgeler nasıl düşünür? (G. Pusar, Çev.). İstanbul: Metis Yayınları.

Çağdaş Sanatın Mecrası: Piyasa (A. Boren, Çev.). (2015, 2 Eylül). Skop Dergi, 8. Erişim adresi: http://www.e-skop.com/skopdergi/cagdas-sanatin-mecrasi-piyasa/2607 (Orijinal kaynak: Foster, H. (2008). The medium is the message. England: London Review of Books)

Danto, A. C. (2017). Sanat nedir. İstanbul: Sel Yayınc1lık.

Ergüven, M. (1992). Yoruma doğru. İstanbul: Yapı Kredi Yayınları.

Franchi, S. \& Güzeldere, G. (2005). Mechanical bodies, computational minds: artificial intelligence from automata to cyborgs. London: The MIT Press.

Gasset, O. (1992). Tarihsel bunalım ve insan. (N. G. Işık, Çev.). İstanbul: Metis Yayınları.

Greenberg, C. (1939). Avangard and Kitsch. (A. Berberoğlu, Çev.). İstanbul: Artist Modern.

Kandinsky, V. (2009). Sanatta Zihinsellik Üzerine. (T. Turan, Çev.). İstanbul: Hayalbaz Yayınları.

Kentridge, W. (2003). Interwiev Carolyn Christov-Bakargiev in conservation with William Kentridge (T. Kırkıl, Çev.). New York: Phaidon.

Kuspit, D. (2006). Sanatın sonu (Y. Tezgiden, Çev.). İstanbul: Metis Yayınları.

Sayın, Z. (2009). Imgenin Pornografisi. İstanbul: Metis Yayınları.

\section{Görsel Kaynakçası}

Görsel 1. A. Elgammal. (Bilim İnsanı). (2018). "Yapay Zekâ Sanat Yaratım Süreci” [Grafik]. Erişim adresi: $\quad \mathrm{https}: /$ theconversation.com/when-the-line-between-machine-and-artist-becomesblurred-103149

Görsel 2. Yapay Zekâ Ürünü. (Yapay Zekâ). (2018). "Edmond Belamy’nin Portresi [Dijital Bask1]. Erişim adresi: https://www.usatoday.com/story/news/nation-now/2018/10/25/painting-createdai-going-auction-block-christies/1759967002/

Görsel 3. Yapay Zekâ Tarafindan Son Birkaç Yılda Üretilen Portre Çalışmaları. (Yapay Zekâ). (20142018). [Dijital Bask1]. Erişim adresi: https://www.inverse.com/article/50043-ai-uses-machinelearning-to-make-art

Görsel 4. F. Bacon. (Sanatçı). (1963). Henrietta Moraes'in Üçlü Portre Çalışması [Resim]. Erişim adresi: https://www.inverse.com/article/50043-ai-uses-machine-learning-to-make-art

Görsel 5. Yapay Zekâ Tarafından Son Birkaç Y1lda Üretilen Diğer Resimler. (Yapay Zekâ). (20142018) [Dijital Bask1]. Erişim adresi: https://its-interesting.com/tag/ahmed-elgammal/ 